\title{
Role of Posyandu as Primary Health Care Services in Implementing Early Detection and Intervention for Autistic Children in Indonesia
}

\author{
Esdaniar Khoirunisa*; Ravik Karsidi; Munawir Yusuf \\ Department of Special Education, Graduate School, Universitas Sebelas Maret, Indonesia \\ Email: esdaniarkhoirunisa@gmail.com
}

http://dx.doi.org/10.18415/ijmmu.v6i1.511

\begin{abstract}
Autism is one of the most complex developmental disorder in children. In the developing country, Autism is a new paradigm, it causes various problems in autism service especially in early detection. It is caused by several factors that interconnected, such as the low understanding of society about autism, the low public awareness about the importance of early detection of autistic children, and the less prioritized attention from the government. Expanding the accessibility of autism services through primary health care is needed to overcome those problems. One of the primary health care most relatable to mother and children is the Maternal and Child Health Center, or in Indonesia it is called "Posyandu" which is an acronym means Integrated service post. The services in Posyandu is not run by professionals such doctor nor midwife. Posyandu is a service-based community and society handled by "posyandu cadres". The aim of this study is to find out how far the possibility of posyandu could provide services for autistic children. The subjects involved in this study were 120 posyandu cadres and 15 parents of autistic children. The research method used is a survey. The results show the following data: $92 \%$ of Posyandu cadres did not know how to do early detection of autistic children, $87 \%$ said they did not know how to handle autistic children, and $87 \%$ of Posyandu cadres felt they still need additional knowledge about autism. While $87 \%$ of parents feel that posyandu cadres are not involved in the early detection of their children. At the same time, 93\% of parents still hope Posyandu could provide better services for their autistic children. This indicates that the primary health care has not fully played a role for autistic children yet, and there is a need to increase autism services access through posyandu cadres.
\end{abstract}

Keywords: Autism; Early Detection; Primary Health Care

\section{Introduction}

Autism is a developmental disorder that appears during early childhood development and lasts throughout one's life (American Psychiatric Association., 2013). Autism is also one of the most complex psychological problems that exist (Feinstein., 2010: 2). There are various challenges that always faced in maximizing services for autistic children, both services related to early detection and early intervention. Another challenge is that autism is seen as a new paradigm. According to Deisinger, (2015) formal records of autism were only available in the past century. Meanwhile, in developing countries, the challenges that faced will be even greater. As in Indonesia, the concept of autism has not really spread 
and fully understood by society, and there are only a few people understand what autism is. According to Tucker (2013), Autism in Indonesia is a fairly new paradigm. It appeared for around past 15-20 years, or around the end of the 1990s. That is why the awareness of autism in Indonesia is still low. The low level of public knowledge about autism caused parents feeling confused about their child's condition. Parents tend to pay attention to the physical health of their babies. When the baby shows good physical health, adequate weight, yet they display unusual behavior and interaction, parents will get confused. They are not aware that the unusuality is a symptom of autism in children (Wike., 2015).

The Indonesian government aims to increase public awareness about autism and improve access for autistic children services in various ways and efforts. One of the practical ways is providing autism service center which spread in several cities in Indonesia. Unfortunately, this service is not evenly spread. Services for children with autism were mostly centered in cities and towns, not reaching yet in remote areas. Moreover, there are still many major problems in child growth and development such as malnutrition and cases of stunting in infants. Therefore, autism spectrum disorder becomes a lower-level priority issue for government.

In this situation, services by non-professional personnel can be an alternative to expand access to autism early detection. This idea is suitable for research by Dereu et. al. (2012) and Janvier et. al. (2016). They both report that with the suitable training, child care worker will able to do early detection of autism spectrum disorder with a standardized instrument. This research proves that non-professional workers potentially capable to give early detection services of autism spectrum disorder in order to improve access to early detection of autism spectrum disorder. according to Tucker (2013) and Wike (2015), primary health care is a potential part in expanding early detection services for autistic children. Especially, the primary health care provider that has intense interaction with mother and child, that is the Maternal and Child Health Centre, or in Indonesia is called "posyandu". Posyandu means integrated service post, it is a service which held by local community independently. This service is focusing on maternal and child health. That is why this service is really important to expand the services for autistic children. They conduct health monitoring, and also make joint efforts to improve public health. But this also raises a big question, can the Posyandu really expand its services for autistic children? Since the personnel of Posyandu is not a professional worker with relevant educational background. They only educated through short training from the public health service to provide basic health services to the community.

This research aims to reveal the possibilities and opportunities for the expansion of services for autistic children by posyandu cadres. As according to Reichow (2013), nowadays research on effective services for persons with mental disabilities by non-professional personnel occupies to the top priority.

\section{The Concept of Autism}

The term of autism or autistic was first introduced by a scientist named Bleuler, which was taken from a Greek word which means self-centered (Volkmar \& Harris., 2013: 341). That Greek term is 'autos', which is related to the characteristics of autism that difficult to undergo interaction with others. According to Diagnostic and Statistical Manual V (2013) autism is a developmental disorder with persistent deficits in social communication and social interaction and Restricted, repetitive patterns of behavior, interests, or activities. According to DSM 5, Autism spectrum disorders mentioned as a neurological development disorder that occurs in early of the child's development. We need to understand that the symptoms of autism spectrum disorder Disorders are quite "disguised". It is because children with autism spectrum disorder autism will not be known through their physical characteristics or even seen as very healthy children (Frith., 2008: 12). 


\section{Characteristic of Autism Spectrum Disorder}

One of the indications of autism spectrum disorder is the restricted and repetitive behaviors and activities (Yates \& Couteur., 2016; DSM V., 2013). Repeated behavior in autistic children is a behavior or some behavior that is shown continuously or also called stereotype behavior (Yates \& Couteur., 2016). Repeated behavior in autistic children can also be seen through the way children play their toys such as lined up toys continuously, and twirling their toys without any attempt to try to play in other ways (Firth., 2008: 11).

In addition to behavior patterns, autism is also characterized by difficulties in establishing interactions and communication with other people. Communication is even called as the core problem of autism spectrum disorder (Thunberg., 2013: 719). Autistic children tend to have improper communication and fairly low communication development (Yates \& Couteur., 2016).

Even though autism shows some obstacles and problems as mentioned above, but basically autistic children have the mental ability that they can use to learn patterns of social interaction, although the way they learn is indifferent from typical children (Frith., 2008: 3). Thus, early detection is very important for autistic children, because it brings to proper early intervention for autistic children.

\section{The Definition of Posyandu}

Posyandu is one of the primary health care services in Indonesia. There are several primary health care services in Indonesia. Some of them are held by professional such as the doctor, midwife, and so all. Meanwhile, posyandu is a health service that is held by the local community, usually a community member who lives in the villages, especially housewife as a volunteer. They called "Poyandu Cadres". Posyandu is an acronym of "pos pelayanan terpadu", which means "integrated service post". In another word, posyandu is "Maternal and Child Health center". It is self-sufficient by the local community. Posyandu provides simple health services, with supervision from the Indonesian health office (Kemenkes RI, 2012). According to the Ministry of Health of the Republic of Indonesia, Posyandu is one of the organizers of community-based primary health care access and community participation.

The role of Posyandu, in general, is to provide health information for the community, and as a driver of society to implement a clean and healthy life. Posyandu has the main task, among others, are monitoring of maternal and child health, family planning promotion, giving immunization to children, monitoring and providing nutrition, and conducting prevention of diarrhea. In relation to services for children under five, Posyandu cadres monitor the condition of children under five, they do recording body weight, head circumference, height, and vitamin giving. Besides, posyandu cadres have a role including homes visiting, parenting counseling, and so on.

\section{Services for Autistic Children by Non-Professional}

According to Hahler and Elsabbagh (2015), countries with low and middle income (Low MiddleIncome Countries (LMICs) always experience almost the same problem that is related to the lack of available budget for the availability of services for autistic children, the need for adaptation of autism instruments to local culture, and the lack of professional health workers that trained to handle autistic children. the limited access to services for autistic children causes the need of efforts to expand the service range of autistic children even though it is done by non-professionals. 
According to Reichow (2013), current, research on effective services for persons with mental disabilities by non-professional personnel or workers who are not experts, occupy the top priority. These studies aimed to overcome the various problems mentioned above in relation to services for autistic children.

Several studies on the services of autistic children by non-professional workers have been carried out. Research by Dereu et. al. (2012) which revealed that with the right early detection standardize instrument, child care workers was able to detect autism in early childhood. The second study was conducted by Janvier et. al. (2016), who conducted research on minority races that far from access of early autism spectrum disorder detection services. Similar results were obtained from this study, that workers in daycare centers were able to do early detection of autism after being given the right training. The research above shows an opportunity to expand access to autism services through non-professional staff. Then the Posyandu also has the same potential in providing services to children with autism, especially in relation to autistic children.

\section{Methodology}

The methods used in this research was survey. The subject of this research were parents of autistic children and posyandu cadres. There were 15 parents of autistic children and 120 posyandu cadres become subject of this research. Posyandu cadres get questions about their knowledge of autistic children and their experience in providing services to autistic children. While parents of autistic children get questions about their satisfaction of service autistic children by the posyandu.

\section{Results}

A total of 120 posyandu officers were involved in this study. They are mostly housewives with ages ranging from 30 to 70 years, and most of them are high school graduate. They first get questions about autism. Have they heard the word autism, do they understand or can distinguish? The results are as follows.

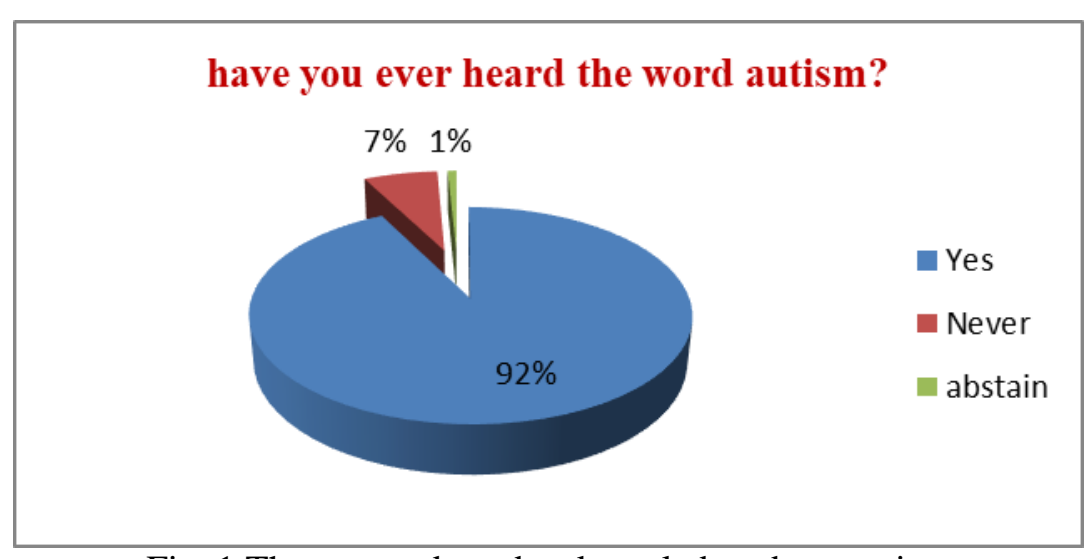

Fig. 1 The posyandu cadres knowledge about autism

Apparently, almost all posyandu cadres have felt that they have heard the word autism, and only $7 \%$ have never heard the word autism. It showed that the term 'autism' is quite popular among posyandu cadres. 
The next questions then narrowed at the ability of Posyandu cadres in early detection and early intervention in autistic children.

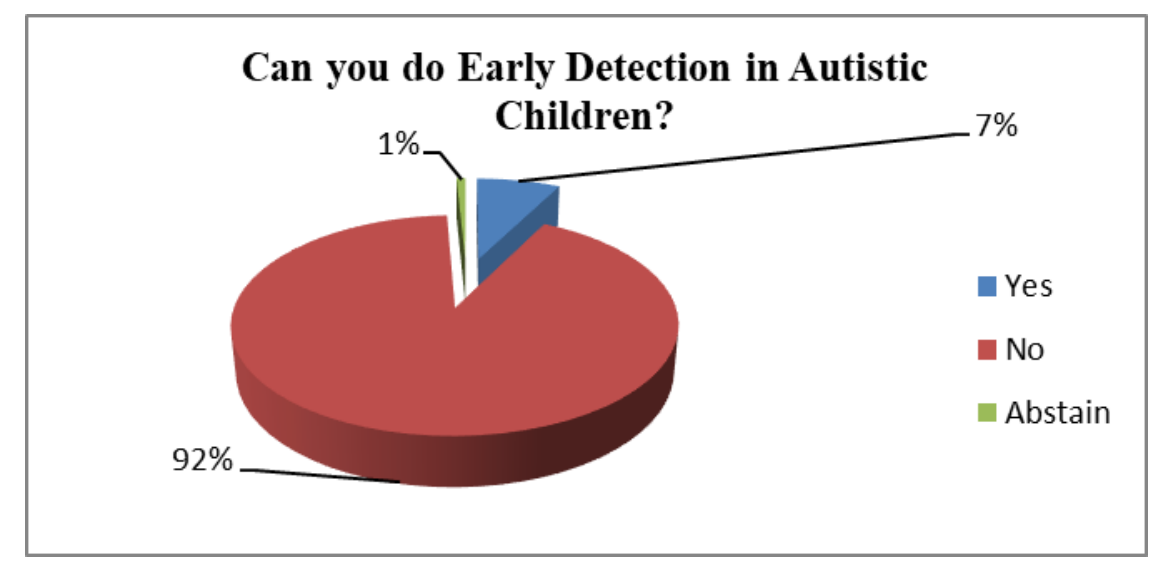

Fig. 2 The posyandu cadres ability in autism early detection ability

The results showed that only $7 \%$ of Posyandu cadres felt that they could carry out early detection in autistic children. Almost all posyandu cadres or as many as $92 \%$ cannot conduct early detection. In addition, the majority of posyandu cadres answered that they did not yet have the skills to deal with autistic children.

Table 1 Skills of Posyandu Cadres in handling autistic children

\begin{tabular}{lcc}
\hline Statement & Frequency & Prosentase \\
\hline Yes & 15 & $12,5 \%$ \\
No & 104 & $86,7 \%$ \\
Abstain & 1 & $0,8 \%$ \\
Total & 120 & $100 \%$ \\
\hline
\end{tabular}

$86.7 \%$ of Posyandu cadres stated that they could not handle autistic children. While posyandu cadres who felt they could handle autistic children were only $12.5 \%$. This data shows that only a small proportion of Posyandu cadres feel they have the skills to deal with autistic children. The data above can be displayed through the pie chart as follows.

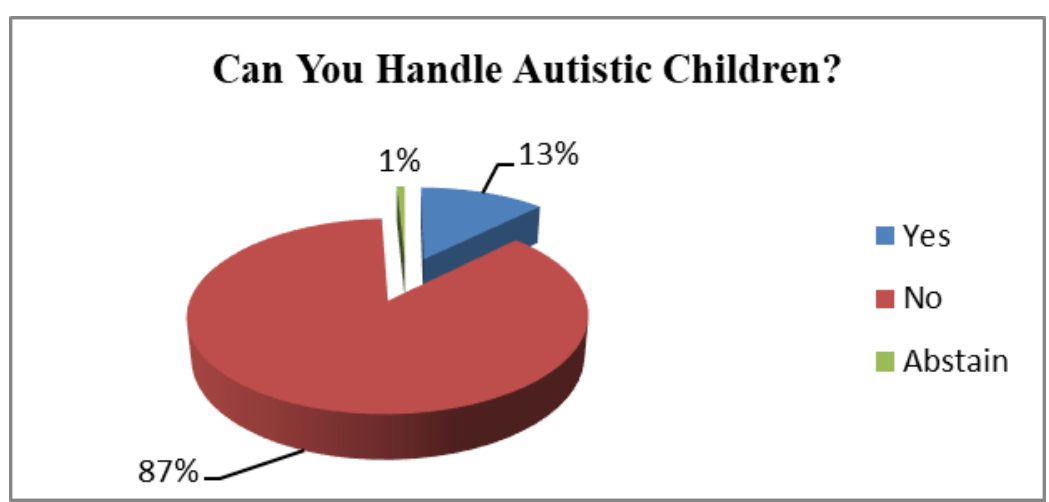

Fig. 3 Posyandu cadre skills in handling autistic children 
According to the data above, Posyandu cadres have less role in providing services to autistic children, therefore posyandu cadres felt that they still needed extra knowledge of autistic children.

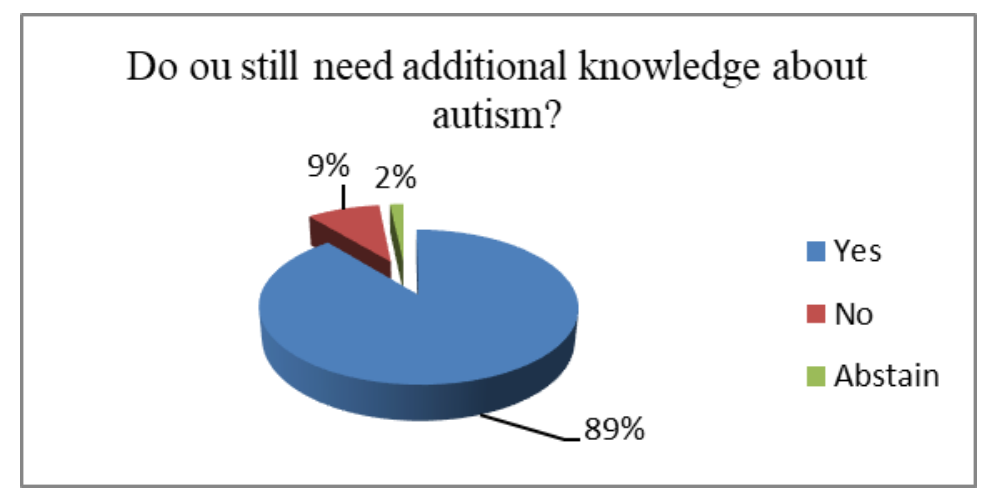

Fig. 4 Posyandu Cadres Needs for Additional Knowledge about Autism

As many as $89 \%$ of Posyandu cadres stated that they still desperately need additional knowledge about children with autism. This shows that the posyandu cadre capacity is indeed still very far from expectations for its role as a service provider for autistic children. This is also evident from a survey conducted on 15 parents of autistic children. They say posyandu does not provide adequate services for autistic children.

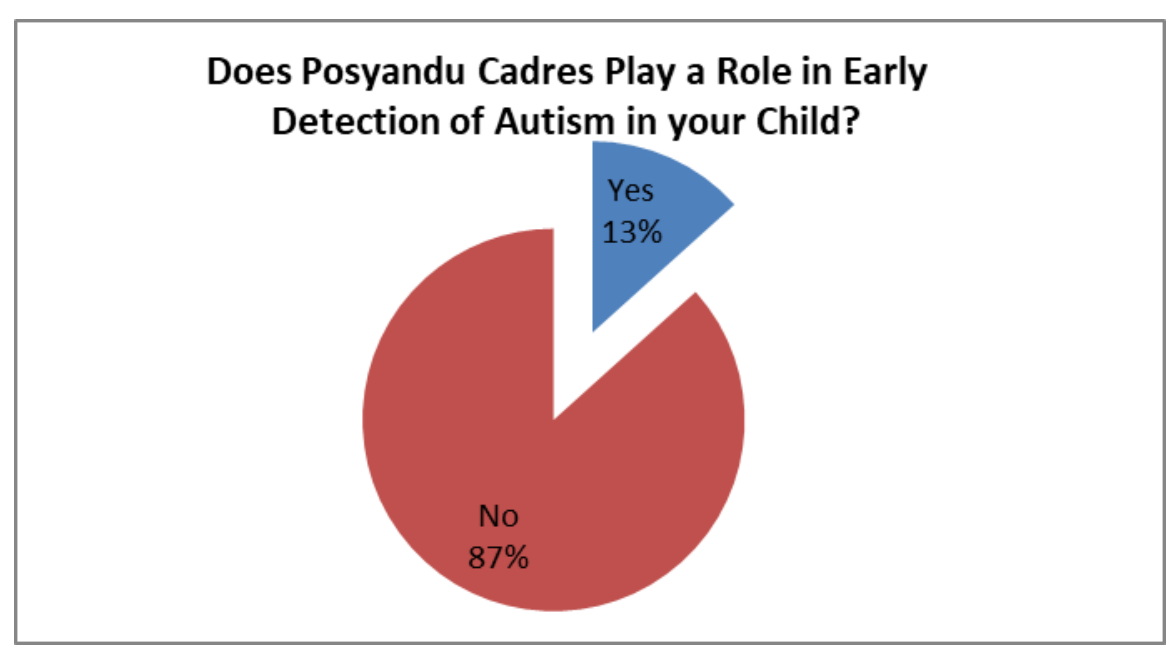

Fig. 5 Parents' opinion regarding the role of posyandu towards early detection of autistic children

The picture above shows a pie chart for the involvement of cadres in early detection of autistic children. $87 \%$ of parents felt that posyandu cadres were not involved in the process of early detection of autistic children, and only $13 \%$ of parents said posyandu cadres were involved in the process of early detection of autistic children. However, parents still have hope for posyandu to improve their services to autistic children. 


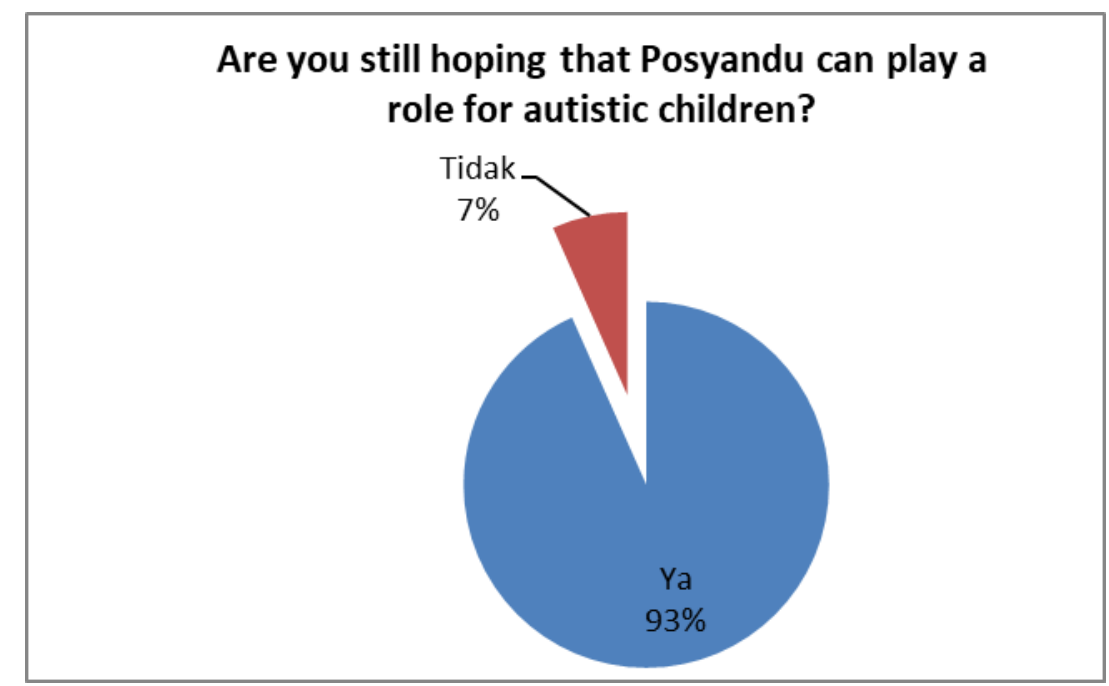

Fig. 6 Parents' expectations for services at the posyandu for autistic children

As many as $93 \%$ of parents said they hoped that Posyandu cadres could improve their services for autistic children.

\section{Conclusion}

This study consisted of several items survey questions for posyandu cadres and parents of autistic children. Based on the data above, for the first item, $92 \%$ of Posyandu cadres had heard the word autism. While the second question item, 92\% of Posyandu cadres said they could not make early detection of autistic children. For the question of the ability to deal with autistic children, $87 \%$ of Posyandu cadres feel unable to handle autistic children, and on questions about the need for additional knowledge of autism, $89 \%$ of cadres answered still needed additional knowledge about autistic children. In addition, in the question items for parents, as many as $87 \%$ of parents felt the posyandu did not contribute anything in the process of early detection of autistic children.

Based on the survey results above, it can be concluded that posyandu services as primary health care have not yet provided maximum service for autistic children. Posyandu in Indonesia is the primary health service that closest to the community. Posyandu is the part that monitors the growth and development of children under five in Indonesia. Almost all toddlers, especially toddlers from middle to lower families, grow and develop with supervision from the posyandu. Therefore, Posyandu has a very important role in increasing the early detection of children with special needs, especially autistic children. In the lack of service for autistic children in Indonesia, there is considerable hope that posyandu can be an alternative service for autistic children.

Apart from existing conditions, Posyandu is actually one of the primary health care services available in Indonesia, which potential to increase service coverage for autistic children. Therefore, an effort to improve the function and role of Posyandu in recognizing the various symptoms of developmental disorders in children, especially autism is needed. The main effort is improving the human resources of Posyandu managers, such as providing various training and education for Posyandu cadres in order to provide more optimal services. 


\section{References}

American Psychiatric Association. (2013). Diagnostic and Statistical Manual of Mental Disorder: Fifth Edition. Washington, DC: American Psychiatric Publishing.

Feinstein, A. (2010). A History of Autism: Conversation with the Pioneers. West Sussex: WileyBlackwell. en.booksee.org.

Deisinger, J. A. (2015). Recent Development in the Diagnosis and Assessment of Autism Spectrum Disorder. Autism and Developmental Disabilities: Current Practices and Issues Advances in Special Education. 18: 85-100. doi:10.1016/S0270-4013(08)18005-9.

Tucker, A. C. (2013). Los Angeles Interpreting and Treating Autism in Javanese Indonesia A dissertation submitted in partial satisfaction of the requirements for the degree Doctor of Philosophy in Culture and Performance by. University of California. Published by ProQuest.

Wike, W. (2015). Mother Perspective in Service Delivery for Children with Autism in a Regional Indonesia City. University od Canberra.

Dereu, M., Ray Maekers, R., Petra Warreyn, Schietecatte I., Meirsschaut, M., Roeyers, H. (2012). Can Child Care Workers Contribute to the Early Detection of Autism Spectrum Disorders? A Comparison Between Screening Instruments with Child Care Worers Versus Parents as Informants. Journal of Autism and Developmental Disorders, 42: 781-796. DOI: 10.1007/s10803-011-1307-9.

Janvier, Y. M., Harris J. F., Coffield, C. N., Louis, B., Xie, M., Cidav, Z., Mandell, D. (2016). Screening for Autism Spectrum Disorder in Underserved Communities: Early Childcare Providers as Reporters. Autism, 20(3): 364-373. DOI: 10.1177/1362361315585055.

Reichow, B., Servili, C., Yasamy, M.T., Barbui, C., Saxena, C. (2013). Non-Specialist Psychological Intervention for Children and Adolescents with Intellectual Disability or Lower-Functioning Autism Spectrum Disorder: A Systematic Review. PLOS Medicine, 10(12). www.plosmedicine.org.

Volkmar, Fred R \& Harris, Irving B. (2013). Autism. Volkmar, F. R (Eds.), Encyclopedia of Autism Spectrum Disorders. (halaman 341). New York: Springer Science+Business Media. DOI 10.1007/9781-4419-1698-3.

Frith, U. (2008). Autism: A Very Short Introduction. New York: Oxford. http://booksee.org/md5/7cb 748e21ce5905fa2a742a466614dc5.

Yates, K. \& Couteur, A. L (2016). Diagnosing Autism/ Autism Spectrum Disorder. Paediatrics and Child Health, 26(12): 513-518. http://dx.doi.org/10.1016/j.paed.2016.08.004.

Thunberg, G. (2013). Early Communication Intervention for Children with Autism Spectrum Disorder. In Recent Advances in Autism Spectrum Disorder, I: 719-746. INTECH. Downloaded from http://www. intechopen.com/books/recent-advances-in-autism- spectrum-disorders-volume-i.

Kementrian Kesehatan RI, Pusat Promosi Kesehatan. (2012). Ayo ke Posyandu Setiap Bulan: Posyand Menjaga Anak dan Ibu Tetap Sehat. Author. www.promkes.depkes.go.id.

Hahler, M. \& Elsabbagh, M. (2015). Autism: A Global Perspective. Current Developmental Disorder Reports, 2: 58-64. DOI 10.1007/s40474-014-0033-3. 


\section{Copyrights}

Copyright for this article is retained by the author(s), with first publication rights granted to the journal.

This is an open-access article distributed under the terms and conditions of the Creative Commons Attribution license (http://creativecommons.org/licenses/by/4.0/). 